\title{
Review
}

\section{Epigenetic Regulation of Cellular Senescence}

\author{
Jack Crouch ${ }^{1}$, Maria Shvedova ${ }^{1}$, Rex Jeya Rajkumar Samdavid Thanapaul ${ }^{1}$, Vladimir Botchkarev ${ }^{2}$ \\ and Daniel Roh ${ }^{1, *}$
}

1 Division of Plastic and Reconstructive Surgery, Department of Surgery, Boston University School of Medicine, Boston, MA 02118, USA; jcrouch@bu.edu (J.C.); mariashv@bu.edu (M.S.); rex@bu.edu (R.J.R.S.T.)

2 Department of Dermatology, Boston University School of Medicine, Boston, MA 02118, USA; vladbotc@bu.edu

* Correspondence: droh@bu.edu

Citation: Crouch, J.; Shvedova, M.; Thanapaul, R.J.R.S.; Botchkarev, V.;

Roh, D. Epigenetic Regulation of Cellular Senescence. Cells 2022, 11, 672. https://doi.org/10.3390/ cells11040672

Academic Editor: Gil Atzmon

Received: 31 December 2021

Accepted: 14 February 2022

Published: 15 February 2022

Publisher's Note: MDPI stays neutral with regard to jurisdictional claims in published maps and institutional affiliations.

Copyright: (c) 2022 by the authors. Licensee MDPI, Basel, Switzerland. This article is an open access article distributed under the terms and conditions of the Creative Commons Attribution (CC BY) license (https:// creativecommons.org/licenses/by/ $4.0 /)$.

\begin{abstract}
Senescence is a complex cellular stress response that abolishes proliferative capacity and generates a unique secretory pattern that is implicated in organismal aging and age-related disease. How a cell transitions to a senescent state is multifactorial and often requires transcriptional regulation of multiple genes. Epigenetic alterations to DNA and chromatin are powerful regulators of genome architecture and gene expression, and they play a crucial role in mediating the induction and maintenance of senescence. This review will highlight the changes in chromatin, DNA methylation, and histone alterations that establish and maintain cellular senescence, alongside the specific epigenetic regulation of the senescence-associated secretory phenotype (SASP).
\end{abstract}

Keywords: senescence; epigenetics; aging; SASP; histone modification; DNA methylation

\section{Introduction}

Cellular senescence is characterized as a hallmark of biological and chronological aging and a potential indicator of pathological tissue states [1]. Senescence also occurs in replicating cells at risk for neoplastic transformation and forces exiting of the cell cycle as a preventative measure against uncontrolled proliferation [2]. More recently, cellular senescence has also been shown to mediate normal wound repair and tissue regeneration, demonstrating its importance in maintaining organismal homeostasis during specific stress challenges [3,4]. Indeed, the expression of $\mathrm{p} 16^{\mathrm{INK} 4 \mathrm{a}}$, a cyclin-dependent kinase inhibitor that blocks cell-cycle progression from the G1 to $S$ phase, is rapidly induced upon wounding, and clearance of these p16+ senescent cells from wound sites significantly delays healing [3,5]. Further, senescent cell populations have been identified throughout embryogenic development in mammalian species, including appropriate development of the inner ear [6] and the mesonephros excretory organ, prior to its transition to the metanephros [7]. Recent literature has suggested widespread epigenetic changes in senescent cells are crucial to the induction, progression, and maintenance of senescence. This review will highlight some of the epigenetic mechanisms mediating cellular senescence.

\section{Cellular Senescence}

Cellular senescence was first described in 1961 when Hayflick and Morehead discovered human lung fibroblasts terminally exit the cell cycle after serial passaging. This phenomenon has since been termed the Hayflick limit [8]. This form of cellular senescence, known as replicative senescence, is mediated primarily by telomere shortening [9]. Since the discovery of cellular senescence, many additional mechanisms that trigger the transition to senescence have been described. In addition to replicative senescence, senescence may be induced via aberrant activation of oncogenes such as $\mathrm{BRAF}^{\mathrm{V} 600 \mathrm{E}}$ or RAS, which mediate cell proliferation and are known drivers of tumor progression and metastasis $[10,11]$. This oncogene-induced senescence (OIS) drives increased expression of genes for proteins involved in cellular respiration, leading to increased generation of reactive oxygen 
species [12]. Escalated levels of reactive oxygen species ultimately result in DNA damage and double-stranded DNA breaks (DSB), which trigger the cell to senesce. DSBs trigger senescence by activating a signaling pathway that results in cell cycle arrest. Briefly, DSBs are sensed by ataxia telangiectasia mutated (ATM) protein, which stabilizes p53, facilitating its binding to the CDKN1A promoter driving translation of p21, a cyclin-dependent kinase inhibitor that prevents cell-cycle progression [13]. In addition, p16 coordinates with p21 in a p53-independent senescence pathway to induce hypophosphorylation of retinoblastoma protein $(\mathrm{Rb})$ which permanently arrests cells in the G1 phase [14]. Mitochondrial dysfunction, driven by mitochondrial DNA depletion, electron transport chain inhibition, or mitochondrial chaperone depletion also drives cellular senescence [15]. Interestingly, investigators demonstrated this senescence was induced independent of DNA damage, a common senescence trigger. Instead, cellular senescence was mediated by AMP-activated protein kinase (AMPK) detection of decreased carbon source availability, driving activation of p53. Further, these senescent cells had a slightly altered SASP secretome compared to replicatively senescent cells, including loss of IL-6, a common SASP factor. While senescent cell-cycle arrest may appear to be a terminal fate, several studies have driven senescent cells to re-enter the cell cycle through conditional knockdown of proteins critical in the promotion and maintenance of senescence [16-18]. These data suggest senescent cell-cycle arrest exists on a continuum, dependent on internal cellular programs and environmental cues.

Senescent cells undergo dramatic phenotypic changes (Figure 1). Morphological changes include flattening and enlargement of senescent cell shape and size. The senescenceassociated $\beta$-galactosidase (SA- $\beta$-gal) is a lysosomal enzyme encoded by the gene GLB1, which accumulates specifically in senescent cells along with the increase in lysosomal content [19]. Impaired biogenesis and mitophagy, alongside decreased membrane potential and increased reactive oxygen species production, are hallmarks of mitochondria in senescent cells [20]. Senescent cells are highly resistant to apoptosis, which may have clinical implications due to their observed accumulation in varied disease states [21,22]. Another unique phenotype to senescent cells is the formation of senescence-associated heterochromatin foci (SAHF), which are specialized regions of facultative heterochromatin that decrease expression of proliferation-promoting genes [23] (see senescence-associated heterochromatin foci section below). Disruption of SAHF integrity was shown to facilitate cell transformation, demonstrating a clear role in tumor suppression via stable suppression of cell-proliferation-associated genes [24]. Nuclear architecture is also disturbed during aging and senescence. The nuclear lamina, a meshwork of proteins just inside the nuclear envelope, provides the nucleus support and stability to maintain its shape and prevent rupture of the membrane. Lamin B1, a key structural protein of the nuclear lamina, decreases in senescent fibroblasts in vitro [25] and in aged human hippocampal astrocytes [26]. Changes in lamin expression and function are just one component in the complex nuclear architectural changes during senescence and aging. For more detail, please refer to recently published reviews $[27,28]$.

Perhaps the most clinically relevant phenotype of senescent cells is the upregulation of senescence-associated secretory phenotype (SASP) genes, a group of proinflammatory cytokines, chemokines, proteases, and growth factors that can drive tissue dysfunction and carcinogenesis [30]. SASP factors, such as IL-6, IL-8, MCP-1, VEGF, and TGF- $\beta$, have been shown to mediate epithelial cell proliferation and have been implicated in the progression and development of various carcinomas [30-32]. Increased secretion of IL-8 by senescent fibroblasts stimulated pancreatic cancer invasion and metastasis in in vitro cell culture and in xenograft mouse models. Further, increased IL-8 production is significantly associated with poorer prognosis for patients with pancreatic cancer [33]. Paradoxically, some secretory elements of the SASP, including TGF- $\beta$, an immunosuppressive cytokine [34], can induce senescence via paracrine signaling to nearby cells, suggesting the SASP secretome is highly regulated with heterogeneous inputs driving different phenotypes $[35,36]$. 


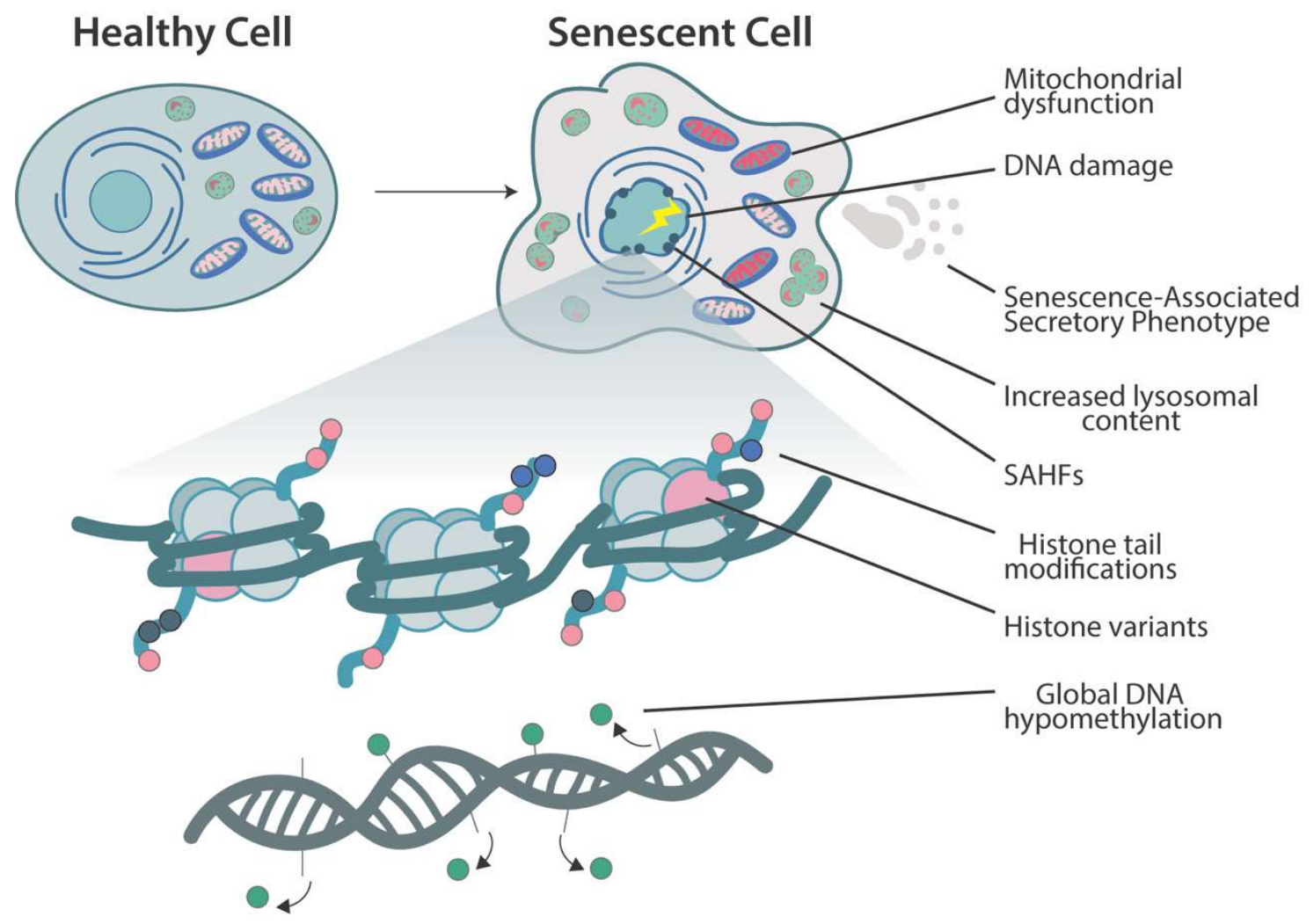

Figure 1. An overview of the morphological, cellular, and epigenomic changes that occur as cell senescence. Morphological alterations include cellular flattening and enlargement. Cellular lysosomal content increases concomitantly with the elevated expression of senescence-associated $\beta$-galactosidase, a highly specific marker for senescence [19]. Mitochondrial abnormalities include impaired biogenesis and mitophagy along with increased reactive oxygen species production and decreased membrane potential [20]. Senescent cells also secrete a heterogeneous group of proinflammatory cytokines, chemokines, proteases, and growth factors that have a profound impact on neighboring cells, known as senescence-associated secretory phenotype (SASP). Large-scale chromatin reorganization occurs with the generation of senescence-associated heterochromatin foci (SAHF), which specifically suppress transcription of pro-proliferation genes [23]. Global hypomethylation of DNA is observed in replicative senescence [29]. Histone variant deposition, histone tail acetylation/methylation, and DNA methylation encompass many of the epigenomic alterations that initiate and maintain cellular senescence.

It is well documented that senescent cells accumulate in aged tissues [37] and are associated with tissue/organ pathology, as well as various disease states [38-40]. The accumulation of senescent cells in tissues is believed to exhaust proliferation-competent cells alongside renewable stem cells, eventually disrupting the functional and regenerative capacity of the tissue $[5,41]$. Elevated $\mathrm{p} 16^{\mathrm{INK} 4 \mathrm{~A}}$ expression was shown to decrease stem cell regeneration across multiple tissue compartments in mice [42,43].

Another feature of aged and senescent cells is a dysregulated metabolome. Recent evidence has demonstrated that nutrient metabolites play an important role in mediating epigenetic enzymatic activity, regulating aging processes, and acting as potent cell signaling agents [44]. Their role in the epigenetic regulation of senescence and aging is important but beyond the scope of this review. For further information, please see recently published reviews $[44,45]$. In addition, many of these metabolites are produced via mitochondrial processes, implicating that these organelles likely play a significant role in regulating epigenome modifying proteins. An ongoing area of research will be to explore how 
mitochondrial dysfunction, epigenetic enzymes, and cellular senescence are integrated. To examine the current literature on this topic, please refer to recent studies [46-49].

\section{Chromatin Changes and Histone-Modifying Enzymes in Senescence}

Eukaryotic chromosomes are generally organized into two architecturally distinct domains: heterochromatin and euchromatin. Heterochromatin is characterized by its relative inaccessibility to transcription factors due to the compact structure of the chromatin. Conversely, euchromatin contains permissive and relaxed regions of DNA that allow for active transcription [50]. Heterochromatin loss and instability are observed in aging, driving increased transcriptional availability of previously repressed genes in multiple organisms, including humans, C. elegans, and S. cerevisiae [51-54]. Premature aging syndromes, including Werner's syndrome and Hutchinson-Gilford progeria syndrome, are characterized by altered structure and loss of heterochromatin [55,56]. In senescent cells, this heterochromatin loss can be partially attributed to persistent DNA damage that drives decreased histone chaperone protein production and decreased histone biosynthesis [57]. Ivanov et al. demonstrated senescent cells bud off pieces of chromatin from the nucleus, known as cytoplasmic chromatin fragments, into the cytoplasm, where they are phagocytosed and degraded by lysosomes, further contributing to senescent cell heterochromatin loss [58].

The many post-translational modifications of histones play fundamental roles in gene expression and alter the structure of chromatin. Histone acetyltransferases (HATs) catalyze the addition of a negatively charged acetyl group to positively charged lysine residues on histone tails protruding from the nucleosome. This mark destabilizes electrostatic interactions between the DNA wrapped around histone cores, allowing for transcription and increased gene expression. Conversely, removal of the acetyl group by histone deacetylases (HDAC) regenerates the stabilizing electrostatic interactions, decreasing transcription and gene expression. Methylation of histone lysine and arginine residues is another generegulating mark. Histone methylation is complex in that residues may be mono-, di-, or trimethylated, and these marks may activate or repress gene transcription [59]. Indeed, diand trimethylation of $\mathrm{H} 3 \mathrm{~K} 4, \mathrm{H} 3 \mathrm{~K} 36$, and $\mathrm{H} 3 \mathrm{~K} 79$ are strongly correlated with active gene transcription, whereas H3K9 and H3K27 methylations repress transcription [60]. There are many other physiologically relevant post-translational histone modifications, including phosphorylation, deimination, ADP-ribosylation, and ubiquitylation that are available for review [59].

\subsection{Polycomb-Group Proteins and Other Histone-Modifying Enzymes}

Polycomb-group (PcG) proteins are highly conserved epigenetic chromatin modifiers that govern stem cell fate [61], are potent regulators of the cell cycle [62], and are upregulated in many cancers [63-66]. Polycomb repressor complexes (PRC) are a specific subset of PcG proteins expressed in proliferating cells and act to repress expression of senescence-associated genes [67-69]. Investigators demonstrated critical recruitment of PRCs by scaffold-attachment factor A (SAFA), a heterogeneous nuclear ribonucleoprotein with diverse functions [70-72], to repress transcription of senescence-associated genes within proliferating cells [73]. The long noncoding RNA, P21-associated noncoding RNA DNA damage-activated (PANDA), has a similar role as SAFA, as depletion within proliferating fibroblasts' stimulated senescence, suggesting important roles in PRC-mediated senescence suppression. Interestingly, in senescent cells, there is a unique interaction between PANDA and nuclear transcription factor $Y$ subunit alpha (NF-YA), a pro-proliferation transcription factor where PANDA acts as a molecular trap, sequestering NF-YA from its normal gene targets, thus decreasing expression. In turn, depletion of PANDA in senescent cells allows for NF-YA to facilitate transcription of proliferation-promoting genes, causing cells to exit senescence and regain proliferative capacity. The regulation of senescence by noncoding RNAs is beyond the scope of this review but has been extensively described in the following reviews [74-76]. 
Deletion of the polycomb repressive complex 2 (PRC2) genes in mice results in embryonic lethality [77], while overexpression of B cell-specific Moloney murine leukemia virus integration site 1 (BMI), a PRC1 protein, downregulates tumor suppressors p16 and p19Arf, driving neoplastic transformation [62]. Recently, investigators demonstrated knockdown of PcG protein, enhancer of zeste homolog 2 (EZH2), an H3K27 methyltransferase, was sufficient to induce senescence and SASP via DNA replication-dependent DNA damage with concomitant p53/p21 induction. They further demonstrated that inducing loss of H3K27me3 marks a transcription repressive trimethylation of the 27th lysine residue of histone $\mathrm{H} 3$, via an EZH2 small-molecule inhibitor was sufficient to elicit cellular senescence even with normal EZH2 protein levels. Interestingly, this second mechanism was shown to prompt senescence without DNA damage or p21 expression. Instead, treatment with the EZH2 inhibitor facilitated senescence via activation of the p16 pathway [78]. Jumonji domain-containing protein 3 (JMJD3), an H3K27 demethylase, has been shown to induce cellular senescence via activation of $\operatorname{Ink} 4 a$, driving p16-dependent arrest in the setting of OIS [79], suggesting a role in tumor suppression.

\subsection{Histone Acetylation}

Histone deacetylase 4 (HDAC4), a deacetylase with diverse cellular functions [80], has roles in senescence regulation. HDAC4 expression was shown to be downregulated similarly in both replication-dependent and oncogene-induced senescent cells [81]. This study examined HDAC4's role in allowing cellular subversion of senescence by knocking out HDAC4 in BJ/hTERT/Ras/E1A cells, which are optimized for senescence bypass through oncogenic transformation. Knockout of HDAC4 promoted senescence of these cells through upregulation of senescence-associated genes, as well as increased SA- $\beta$ galactosidase activity, a highly specific marker for senescence. Further, eliminating HDAC4 in leiomyosarcomas, cancers known for high expression of HDAC4, led to senescence, arrested proliferation, and enriched SASP factors. In a later study, these investigators demonstrated specific HDAC4/H3K27ac interactions at senescence super-enhancer regions via ChIP-seq [82], solidifying HDAC4's role as a supervisor of the senescence program. shRNA knockdown of p300, a HAT, significantly delayed replicative senescence in fibroblasts and displayed fewer telomere dysfunction-induced foci, which indicate decreased DNA damage [83]. However, overexpression of p300 was insufficient to drive premature senescence. The study further elucidated p300's role in regulating senescence by demonstrating that p300 depletion drove a significant decrease in expression of super-enhancer target genes. Finally, ChIP-seq experiments demonstrated direct interactions between p300 and the senescence-associated super-enhancer regions establishing p300 as the main driver of senescence-related acetylation at these regions.

\subsection{Senescence-Associated Heterochromatin Foci}

Senescence drives specialized regions of facultative heterochromatin, which silences proliferation-promoting genes, forming senescence-associated heterochromatin foci (SAHF) [23]. SAHFs have been characterized as a multilayer concentric structure with repressive H3K9me3 marks localizing to a "core" and H3K27me3 marks, forming a "ring" around said core. Interestingly, these repressive marks are not required for the formation of the SAHF, suggesting that deposition of these marks is an independent event from the heterochromatin compaction [84]. SAHF-positive senescent cells have also been found to be completely devoid of linker histone $\mathrm{H1}$, a major protein involved in the stabilization of both DNA wrapped around the nucleosome and chromatin fibers between nucleosomes [85]. Depletion of suppressor of variegation 3-9 homolog 1 (SUV39h1), a histone H3 lysine 9 methyltransferase and a critical enzyme in SAHF formation, promoted tumor progression in a neuroblastoma Ras-induced oncogene transgenic mouse model, suggesting that SAHF are important in preventing neoplastic transformation [86]. After treatment with cell-cycle inhibitors or DNA-damaging agents, ATP-dependent helicase (ATRX), a chromatin-remodeling enzyme, was found to be critical for the development of the SAHF via interactions with H3K9me3 
and heterochromatin protein 1 gamma (HP1 $\gamma)$, a nonhistone chromatin-binding protein that drives gene suppression. Further, knockdown of ATRX prevented formation of SAHF in vitro [87]. Investigators demonstrated an $\mathrm{Rb}$-deficient breast cancer cell line fails to form SAHF following treatment with the DNA-damaging agent. Further, knockdown of Rb in a cancer cell line inhibited SAHF formation in response to doxorubicin, suggesting Rb may play a role in tumor cell SAHF formation after treatment with DNA-damaging agents [88]. These investigators went on to demonstrate that JMJD3 is transported to the cytoplasm and demethylates $\mathrm{Rb}$, facilitating assembly of the SAHF [89]. Importantly, the data discussed above were performed in vitro utilizing human fibroblast cell lines. Recent literature has demonstrated that SAHF formation is dependent on cell type and the senescence induction method. Lentiviral oncogene induction drove SAHF formation in two fibroblast cell lines and keratinocytes. However, exposure to cytotoxic chemotherapeutics, bacterial toxins known to induce senescence, and serial passaging only induced SAHF formation in some fibroblast cell lines and did not induce SAHF in keratinocytes [90]. Further, the authors demonstrated that SAHFs were not detectable in $\beta$-galactosidase-positive cells of healthy human bladder and colon tissues alongside urinary bladder and colorectal tumors. The data above suggest that SAHF formation is not a universal mechanism of senescence and is tissue type and senescence induction method dependent.

\subsection{Histone Variants}

Histone variants of the canonical histone proteins $\mathrm{H} 2 \mathrm{~A}, \mathrm{H} 2 \mathrm{~B}, \mathrm{H} 3$, and $\mathrm{H} 4$ have crucial roles in transcriptional regulation, chromosome segregation, DNA repair, and generation and maintenance of epigenetic states [91]. While most canonical histones are deposited during the $S$ phase of cellular replication, variants can be deposited in a replication-dependent or -independent manner [91]. Replication-induced senescent cells are characterized by a variety of canonical histone replacements by histone variants. H3 is cleaved by lysosomal protease cathepsin L1 (CTSL1), after its localization to the nucleus via Ras activation, to H3.3, and CTSL1 inhibition prevents formation of the SAHF. Further, ectopic expression of H3.3 induced senescence in fibroblasts, demonstrating H3.3's role in senescence-specific heterochromatin alterations [92]. H3.3 chromatin deposition is mediated by histone chaperone HIRA. Coordination of HIRA and H3.3 is critical for senescence induction, as investigators demonstrated large-scale neoplastic transformation in an oncogenic Braf mouse model via inactivation of HIRA [93]. SAHFs are enriched with another histone variant, macroH2A. Indeed, HIRA/antisilencing function 1A Histone chaperone (ASF1A)-mediated macroH2A deposition is necessary for the stable formation of the SAHF and was determined to be the rate-limiting step in SAHF formation [94]. Another variant, H2A.J, was found to accumulate in senescent human fibroblasts and aged mice in the setting of persistent DNA damage. Knockdown of H2A.J decreased expression of common SASP-associated genes, and overexpression of H2A.J in nonsenescent proliferating cells increased expression of SASP-associated genes, highlighting the importance of this histone variant in facilitating the senescence phenotype [95].

Unlike previously mentioned variants that facilitate and maintain senescence, H2A.Z is a potent suppressor of senescence induction in proliferating cells by localizing to p53 binding sites at the $\mathrm{p} 21$ promoter. Upon treatment with a DNA-damaging agent, ChIP assay confirmed eviction of H2A.Z from the p21 promoter, allowing p53 binding and inducing cellular senescence. Further, depletion of H2A.Z from primary fibroblasts was sufficient to induce senescence [96].

$\gamma-\mathrm{H} 2 \mathrm{AX}$, which denotes phosphorylation of the Ser-139 residue of the histone variant $\mathrm{H} 2 \mathrm{AX}$, is a histone variant that is present at double-stranded DNA breaks (DSB) where it colocalizes to the DSB, inducing a rapid epigenetic response to drive resolution of the break [9]. Further, $\gamma$-H2AX foci are widely observed in the nuclei of senescent cells and cells that have undergone significant telomere shortening [97]. 
Altogether, variant histones are highly abundant in senescent cells relative to their proliferating cell counterparts, stabilizing and maintaining SAHFs, as well as facilitating SASP factor gene expression, allowing for sustained cellular senescence.

\section{DNA Methylation}

DNA methylation is a powerful epigenetic regulatory modification that promotes transcriptional silencing. In replicative senescence, an overall decrease in DNA methylation was observed in senescent cells compared to proliferating cells. This hypomethylation was attributed to a failure of DNA methyltransferase 1 (DNMT1) to maintain methylation over many repeated replication cycles, which drives decreased expression of DNMT1 [29] and delocalization of the enzyme out of the nucleus [98]. Methylation patterns vary across types of senescence, as demonstrated by Sakaki et al. Their investigation revealed altered DNA methylation patterns in replicative senescent cells compared to their proliferating cell counterparts. Hypomethylation was specifically enriched at $\mathrm{CpG}$ sites related to immune response genes. Interestingly, little change was observed in methylation patterns for premature induction of senescence via Ras-induced oncogenic stress. Cellular senescence induction via oncogenic stress in cells that had undergone several rounds of replication recapitulated the methylation patterns observed in replicative senescent cells. Further, hypomethylation was enriched by nonCpG island promoters of immune response-related genes, suggesting a role in the upregulation of certain SASP genes [99].

DNA methylation and subsequent oxidation of 5-methylcytosine (5-mC) into 5-hydrox ymethylcytosine $(5 \mathrm{hmC})$ are key epigenetic events regulating development and stem cell differentiation in mammals [100-102]. The process of 5-mC conversion toward an unmethylated state also includes formation of 5-formylcytosine and 5-carboxycytosine [103]. Oxidation of $5-\mathrm{mC}$ is catalyzed by the ten-eleven translocation (Tet) family enzymes (Tet1/2/3) and serve as an important step in DNA demethylation [104]. In addition to 5-mC oxidation at gene regulatory regions and CpG islands, Tet proteins are also capable of positively regulating gene transcription by activating enhancers via DNA demethylation [102,105].

Increasing evidence suggests that Tet enzymes contribute to aging of reproductive and hematopoietic systems. Tet1 deficiency reduces fertility and leads to accelerated reproductive failure (premature ovarian insufficiency) syndrome with age [106]. Tet1-deficient mice undergo a progressive reduction of spermatogonia stem cells and spermatogenesis resulting in accelerated infertility with age [107]. Somatic TET2 mutations contribute to myeloid expansion and innate immune dysregulation with age accompanied by an increased risk of transformation to hematological malignancies, including myeloproliferative and myelodysplastic neoplasms and acute myeloid leukemia [108].

An "epigenetic clock" has been proposed via next-generation sequencing technology that describes highly reproducible patterns of methylation that can accurately predict human chronological age [109]. Further, this DNA methylation clock has been established across multiple murine strains, including many tissue types [110]. Cell passage numbers and population doublings of in vitro cell cultures may also be predicted via analysis of methylation patterns to specific CpG sites [111]. Age-associated and senescence-associated changes in DNA methylation share considerable overlap, but do harbor distinct differences at specific CpG sites, most commonly found at Hox genes and genes mediating cellular differentiation [112]. The similarities observed suggest both aging and senescence are regulated by similar mechanisms. Previous reports also demonstrated striking similarities between the global methylation profile of senescent cells and those of cancer cells [98,113], suggesting premalignant senescent cells may facilitate malignant transformation if senescence is bypassed. However, a more recent analysis of the senescent cell methylation demonstrated key local differences in methylation events between replicative senescence and transformation [114]. Indeed, in senescent cells, programmed methylation of CpGs was found in promoter regions of genes regulating metabolism and cellular biosynthesis. Conversely, stochastic methylation of genes regulating cell differentiation and development was found in transformed cells that may drive self-renewal and block differentiation. 
Recent studies further interrogated the epigenetic clock to recapitulate a juvenile epigenetic profile in aged cells. Investigators transfected aged primary human fibroblasts and endothelial cells with an mRNA cocktail expressing OSKMLN, the canonical induced pluripotent stem cell (iPSC) reprogramming factors. This specific methodology allows for epigenetic reprogramming without altering the original cell identity. After treatment, aged primary cells exhibited a rapid reversion of their epigenetic clock methylation pattern, appearing similar to their young cell counterparts. Immunofluorescence data further demonstrated a youthful epigenetic profile with increased nuclear staining of $\mathrm{H} 3 \mathrm{~K} 9 \mathrm{me} 3$, $\mathrm{HP} 1 \gamma$, and lamin-associated polypeptide $2 \alpha$ (LAP2 $\alpha$ ), a nuclear lamin support protein. Further evidence of improved cellular function included increased SIRT1 expression, decreased mitochondrial reactive oxygen species, and improved active clearance of cellular waste and macromolecules. [115]. This model has also been utilized in replicatively senescent human donor fibroblasts and human cell line fibroblasts [116]. Lapasset et al. showed in both groups of cells decreased markers of senescence, including disappearance of SAHFs, downregulated expression of $\mathrm{p} 16^{\mathrm{INK} 4 \mathrm{~A}}$ and $\mathrm{p} 21^{\mathrm{CIP} 1}$, increased telomere length, and restoration of proliferation capacity. In vivo reprogramming was also used in the LAKI progeroid mouse model, which harbors a mutation in the lamin A gene. Short-term cyclic expression of OSKM restored heterochromatin maintenance marks H3K9me3 and H4K20me3 to healthy levels. Liver cells isolated from these mice harbored significantly fewer SA- $\beta-\mathrm{Gal}$ positive cells compared to control mice. Furthermore, fibroblasts harvested from these progeroid mice that underwent reprogramming demonstrated increased mitochondrial function, reduced cellular senescence evidenced by Il- 6 and $\beta$-galactosidase expression, and decreased DNA damage [117]. This transfection method was used to restore youthful DNA methylation patterns and transcriptomes in aged mouse CNS tissue leading to increased axon regeneration after injury and restored vision loss in an aged mouse glaucoma model [118].

Altogether, alterations in DNA methylation and DNA methylation associated enzymes during aging and senescence significantly contribute to cellular dysfunction, facilitate a chronic inflammatory state via SASP activation, and may mediate certain age-related pathologies.

\section{Epigenetic Regulation of SASP}

High-mobility-group protein B2 (HMGB2), a multifunction protein involved in chromatin remodeling, transcription regulation, and DNA repair [119], binds loci of SASP genes, preventing their incorporation into the SAHF during senescence, thus facilitating active transcription (Figure 2). Inhibition of HMGB2 decreases SASP in senescent cells without preventing formation of the SAHF. Incorporation of the IL8 gene locus into the SAHF was demonstrated to repress this SASP factor in HMGB2 knockdown senescent cells. Targeting this pathway may allow beneficial repression of neoplastic transformation and proliferation genes via cellular senescence while inhibiting a chronic proinflammatory and protumorigenic environment of SASP factors [120].

Chromatin remodeling events during cellular senescence drive the formation of superenhancers at SASP gene loci to facilitate transcription. Increasing H3K27 acetylation at these super-enhancer sites and recruitment of Bromodomain-containing protein 4 (BRD4) is necessary for upregulated expression of key SASP genes and inhibition of BRD4 suppressed SASP expression. Further, pharmacological inhibition of BRD4 allowed for immune escape and decreased clearance of premalignant senescent hepatocytes in a liver cancer mouse model [121].

The H3K4 methyltransferase, mixed-lineage leukemia 1 (MLL1), is required for SASP activation, as silencing of MLL1 with shRNA dramatically decreased expression of key SASP genes, including IL-1A, IL-8, IL-6, MMP1, and MMP3m in OIS-transformed fibroblasts and OIS primary human melanocytes. Interestingly, inhibition of MLL1 blocked the expression of SASP-like proteins in response to DNA damage that did not induce senescence, suggesting an anti-inflammatory role independent of senescence [122]. Disruptor of 
telomeric silencing 1-like (DOT1L), a histone-specific methyltransferase, was shown to be necessary for methylation of $\mathrm{H} 3 \mathrm{~K} 79$ at the IL1A gene locus, driving increased transcription. Like MLL1, this phenomenon was independent of senescence-induced cell-cycle arrest, making MLL1 and DOT1L potential therapeutic targets to limit the negative consequences of SASP factors of the tissue environment without losing the antineoplastic transformation effect of senescence [123].

The DDR during senescence promotes proteasomal degradation of G9a and G9a-like protein, both $\mathrm{H} 3 \mathrm{~K} 9$ histone methyltransferases. In senescence-induced cells, Cdc14B- and p21-dependent activation of APC / C ubiquitin ligase drive decreased H3K9 methylation, allowing for increased expression of IL-6 and IL-8 [124]. JMJD3 was found to be upregulated in several transformed glioma cell lines compared to healthy astrocytes. Further, ectopic overexpression of JMJD3 within a glioma cell line promoted SASP-associated gene expression and induced senescence suggesting JMJD3's demethylase activity mediates SASP activation [125].

NAD-dependent deacetylase sirtuin-1 (SIRT-1) negatively regulates SASP genes. During cellular senescence, decreased expression of SIRT-1 allows for increased acetylation of H3K9 and H4K16 driving transcription of these cytokines, a phenomenon recapitulated in nonsenescent SIRT-1 depleted cells [126]. Interestingly, while DNA damage and senescence are generally inextricably tied, treatment of proliferating cells with sodium butyrate, an HDAC inhibitor, induced senescence and promoted expression of SASP genes in the absence of DNA damage $[127,128]$. This finding suggests chromatin remodeling due to the DDR pathway may be the significant driver of SASP expression, as opposed to physical breaks within DNA.

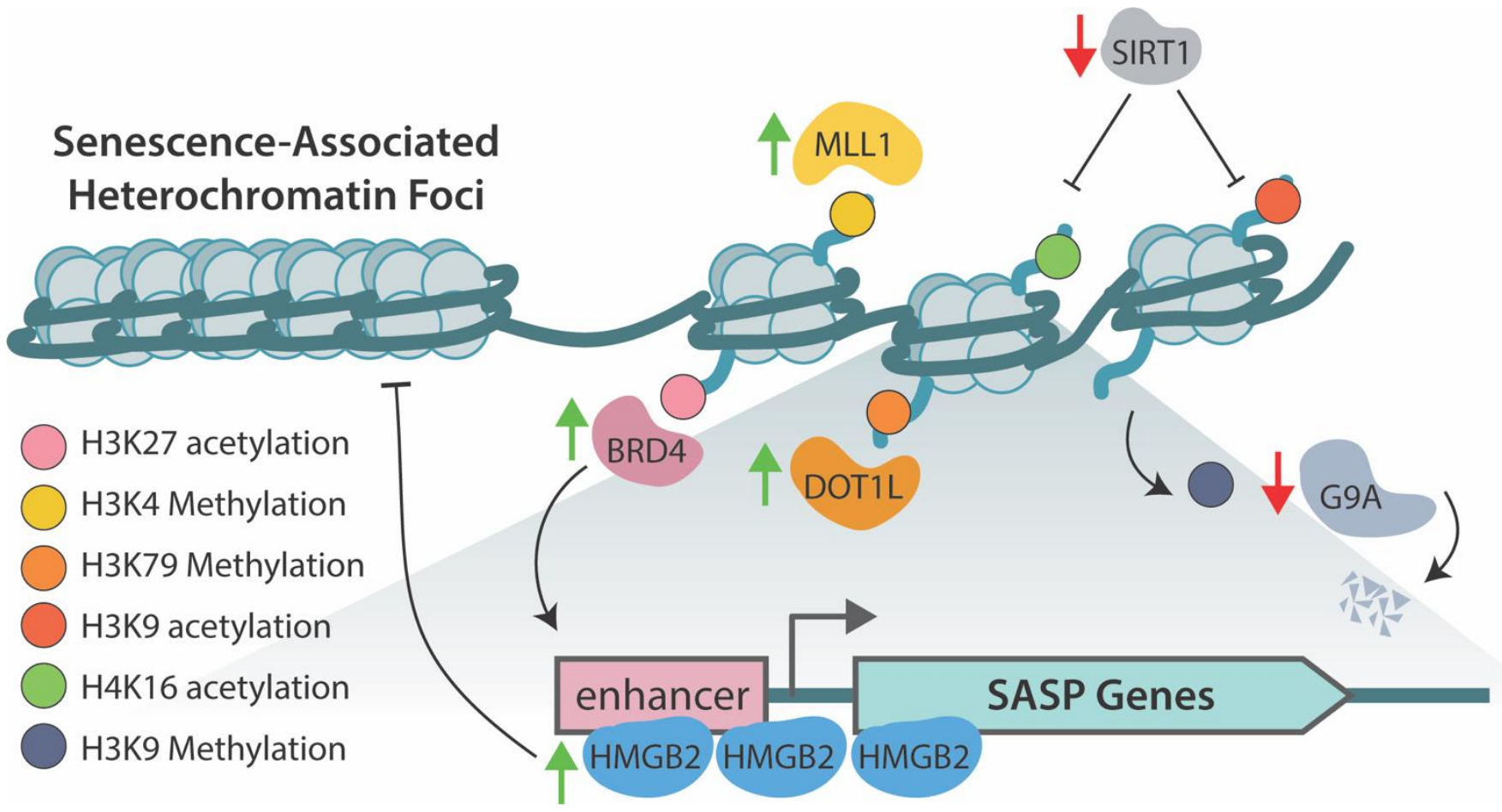

Figure 2. An overview of the histone acetylation/methylation marks and proteins that regulate genes involved in the senescence-associated secretory phenotype (SASP). High-mobility-group protein B2 (HMGB2) binds loci of key SASP genes preventing their incorporation into the SAHF during senescence allowing for their transcription [120]. Mixed-lineage leukemia 1 (MLL1) methylates H3 at Lys-4 to promote transcription of SASP genes [122]. Disruptor of telomeric silencing 1-like (DOT1L) mediates methylation of $\mathrm{H} 3$ at Lys-79 driving transcription of potent inflammatory cytokine and SASP factor IL1A [123]. Bromodomain-containing protein 4 (BRD4) mediated acetylation of H3 at Lys-27 is necessary to drive transcription of SASP factors during senescence [121]. G9a and G9a-like 
proteins, which deposit repressive methylation on $\mathrm{H} 3$ at Lys-9, prevent transcription of SASP genes in proliferating cells [124]. In response to DNA damage, these proteins are degraded, allowing for active transcription of IL-6 and IL-8. NAD-dependent deacetylase sirtuin-1 (SIRT-1) negatively regulates SASP expression through deacetylation of H4 Lys-16 and H3 Lys-9 in normal proliferating cells. Senescence induction decreases expression of SIRT-1, allowing for acetylation and expression of key SASP genes [126].

\section{Therapeutics Targeting Epigenetic Mechanisms}

As more data implicate epigenetic regulatory mechanisms of gene expression playing an integral role in the manifestation and maintenance of age-related diseases, investigation has turned toward therapies that combat these pathologies alongside promoting health and lifespan. Resveratrol is a sirtuin-1 activator that has improved health and lifespan in many species, including mice [129-131], but its clinical efficacy as a therapeutic in humans is less well understood. HDAC inhibitors are a group of therapeutics with diverse structure, specificity, and biological activity that prevent deacetylation of histone tails. Their improvement of healthspan and amelioration of disease states has been well documented in many species, including rodents. HDAC inhibitor treatment improved neuronal health, cognitive function, and memory in neurodegenerative rodent models, including Alzheimer's disease [132], amyotrophic lateral sclerosis [133], and Parkinson's disease [134]. HDAC inhibitors also prevented obesity, preserved insulin sensitivity, and improved mitochondrial function in mice fed a high-fat diet compared to their control littermates [135,136]. Currently, five HDAC inhibitors have been approved by the US Food and Drug Administration (FDA), vorinostat, romidepsin, tucidinostat, Panobinostat, and belinostat. Romidepsin and vorinostat are current therapies in the treatment of cutaneous T-cell lymphoma $[137,138]$. Romidepsin and belinostat are used for treating peripheral T-cell lymphoma $[139,140]$. DNMT inhibitors are another class of epigenetic regulation targeting drugs that have found efficacy in treating cancer. Azacitidine and decitabine are antimetabolite DNMT inhibitors with efficacy in acute myeloid leukemia, chronic myelomonocytic leukemia, and myelodysplastic syndrome [141]. Tazemetostat is an EZH2 inhibitor that is used in the treatment of non-Hodgkin's lymphoma [142]. Importantly, these epi-drugs are not without their limitations. As seen above, their use has been primarily restricted to cancers of hematologic origin. Indeed, their efficacy as monotherapies against solid tumor cancers is poor. However, there is growing preclinical evidence that combination therapies of HDAC inhibitors or other epi-drugs paired with other anticancer therapeutics may be more effective in treating solid tumor cancers. For example, tamoxifen paired with an HDAC inhibitor was effective in the treatment of hormone-sensitive breast cancer and helped prevent or reverse cancer resistance [143,144]. Another limitation of epi-drugs is their distinct lack of specificity leading to significant off-target effects and cytotoxicity. Continued study of the histone code is imperative to generate more specific therapies that can maximize effectiveness against cancer cells and minimize toxicity to healthy cells. For more detail on epi-drugs, please see current reviews [145-147].

\section{Conclusions and Future Perspectives/Directions}

Drugs targeting epigenetic pathways remain an exciting field of therapeutics; however, they are currently targeted towards hematologic cancers. Continuation of research examining the histone code, epigenetic protein/nucleotide interactions, and combination therapies will improve the efficacy of these drugs, limit unintended effects, and perhaps expand their usefulness therapeutic to additional domains such as senescence and aging. As discussed, epigenetic changes in senescence are diverse and dynamic, and there is no universal phenotype of senescent cells. As epigenetic regulation of senescence is dependent on tissue and cell type, as well as a senescence induction method, there is a need for expansion of the tissue types and cells studied during senescence induction would allow better insight into how different cell types may reorganize chromatin due to various senescence-promoting stimuli. 
Large-scale chromatin remodeling, histone alterations, and DNA methylation activate or repress cellular senescence in response to a variety of stimuli, including DNA damage, oncogenic stress, mitochondrial dysfunction, and metabolic stress. Further, some epigenetic phenotypes and pathways may be highly specific to various senescence-inducing sources, with others having dramatic overlap. Young, healthy cells maintain an epigenome that promotes precise regulation of gene expression, thus avoiding replicative and oxidative stress. Conversely, aged cells accumulate stochastic insults over time, driving alterations in gene expression, decreased fitness and functionality, ultimately leading to cell-cycle arrest and senescent states. The reversible capacity of these tightly regulated epigenetic pathways and mechanisms serves as a potential source for therapy in myriad disease states caused by senescence.

Funding: This work was supported by the grants from the National Institutes of Aging (R03AG067983) and NIAMS (R61AR078093, R01AR071727, R01AR075776), Laszlo N. Tauber Professorship in Surgery; Boston Claude D. Pepper Older Americans Independence Center (NIA) Research Education Core Award 5P30AG031679-10: Subaward 115900.

Conflicts of Interest: The authors declare no conflict of interest.

\section{References}

1. López-Otín, C.; Blasco, M.A.; Partridge, L.; Serrano, M.; Kroemer, G. The hallmarks of aging. Cell 2013, 153, 1194-1217. [CrossRef] [PubMed]

2. Campisi, J. Cellular senescence as a tumor-suppressor mechanism. Trends Cell Biol. 2001, 11, S27-S31. [CrossRef]

3. Demaria, M.; Ohtani, N.; Youssef, S.A.; Rodier, F.; Toussaint, W.; Mitchell, J.R.; Laberge, R.-M.; Vijg, J.; Van Steeg, H.; Dollé, M.E.; et al. An Essential Role for Senescent Cells in Optimal Wound Healing through Secretion of PDGF-AA. Dev. Cell 2014, 31, 722-733. [CrossRef]

4. $\quad$ Ritschka, B.; Storer, M.; Mas, A.; Heinzmann, F.; Ortells, M.C.; Morton, J.P.; Sansom, O.J.; Zender, L.; Keyes, W.M. The senescenceassociated secretory phenotype induces cellular plasticity and tissue regeneration. Genes Dev. 2017, 31, 172-183. [CrossRef]

5. Baker, D.J.; Childs, B.G.; Durik, M.; Wijers, M.E.; Sieben, C.J.; Zhong, J.; Saltness, R.A.; Jeganathan, K.B.; Verzosa, G.C.; Pezeshki, A.; et al. Naturally occurring p16Ink4a-positive cells shorten healthy lifespan. Nature 2016, 530, 184-189. [CrossRef] [PubMed]

6. Gibaja, A.; Aburto, M.R.; Pulido, S.; Collado, M.; Hurle, J.M.; Varela-Nieto, I.; Magariños, M. TGFß2-induced senescence during early inner ear development. Sci. Rep. 2019, 9, 5912. [CrossRef] [PubMed]

7. Muñoz-Espín, D.; Cañamero, M.; Maraver, A.; López, G.G.; Contreras, J.; Murillo-Cuesta, S.; Rodríguez-Baeza, A.; Varela-Nieto, I.; Ruberte, J.; Collado, M.; et al. Programmed Cell Senescence during Mammalian Embryonic Development. Cell 2013, 155, 1104-1118. [CrossRef]

8. Hayflick, L.; Moorhead, P.S. The serial cultivation of human diploid cell strains. Exp. Cell Res. 1961, 25, 585-621. [CrossRef]

9. Bernadotte, A.; Mikhelson, V.M.; Spivak, I.M. Markers of cellular senescence. Telomere shortening as a marker of cellular senescence. Aging 2016, 8, 3-11. [CrossRef]

10. Di Micco, R.; Fumagalli, M.; Cicalese, A.; Piccinin, S.; Gasparini, P.; Luise, C.; Schurra, C.; Garre, M.; Nuciforo, P.; Bensimon, A.; et al. Oncogene-induced senescence is a DNA damage response triggered by DNA hyper-replication. Nature 2006, 444, 638-642. [CrossRef]

11. Michaloglou, C.; Vredeveld, L.C.; Soengas, M.S.; Denoyelle, C.; Kuilman, T.; Van Der Horst, C.M.; Majoor, D.M.; Shay, J.W.; Mooi, W.J.; Peeper, D.S. BRAF E600-associated senescence-like cell cycle arrest of human naevi. Nature 2005, 436, 720-724. [CrossRef] [PubMed]

12. Li, M.; Durbin, K.R.; Sweet, S.M.; Tipton, J.D.; Zheng, Y.; Kelleher, N.L. Oncogene-induced cellular senescence elicits an anti-W arburg effect. Proteomics 2013, 13, 2585-2596. [CrossRef] [PubMed]

13. Karimian, A.; Ahmadi, Y.; Yousefi, B. Multiple functions of p21 in cell cycle, apoptosis and transcriptional regulation after DNA damage. DNA Repair 2016, 42, 63-71. [CrossRef]

14. Yang, N.; Sen, P. The senescent cell epigenome. Aging 2018, 10, 3590-3609. [CrossRef] [PubMed]

15. Wiley, C.D.; Velarde, M.C.; Lecot, P.; Liu, S.; Sarnoski, E.A.; Freund, A.; Shirakawa, K.; Lim, H.W.; Davis, S.S.; Ramanathan, A.; et al. Mitochondrial Dysfunction Induces Senescence with a Distinct Secretory Phenotype. Cell Metab. 2016, 23, 303-314. [CrossRef] [PubMed]

16. Milanovic, M.; Fan, D.N.Y.; Belenki, D.; Däbritz, J.H.M.; Zhao, Z.; Yu, Y.; Dörr, J.R.; Dimitrova, L.; Lenze, D.; Barbosa, I.A.M.; et al. Senescence-associated reprogramming promotes cancer stemness. Nature 2017, 553, 96-100. [CrossRef] [PubMed]

17. Sage, J.; Miller, A.L.; Pérez-Mancera, P.A.; Wysocki, J.M.; Jacks, T. Acute mutation of retinoblastoma gene function is sufficient for cell cycle re-entry. Nature 2003, 424, 223-228. [CrossRef]

18. Beauséjour, C.M.; Krtolica, A.; Galimi, F.; Narita, M.; Lowe, S.W.; Yaswen, P.; Campisi, J. Reversal of human cellular senescence: Roles of the p53 and p16 pathways. EMBO J. 2003, 22, 4212-4222. [CrossRef] 
19. Wang, A.S.; Dreesen, O. Biomarkers of cellular senescence and skin aging. Front. Genet. 2018, 9, 247. [CrossRef]

20. Vasileiou, P.V.; Evangelou, K.; Vlasis, K.; Fildisis, G.; Panayiotidis, M.I.; Chronopoulos, E.; Passias, P.-G.; Kouloukoussa, M.; Gorgoulis, V.G.; Havaki, S. Mitochondrial Homeostasis and Cellular Senescence. Cells 2019, 8, 686. [CrossRef]

21. Chen, Q.M.; Liu, J.; Merrett, J.B. Apoptosis or senescence-like growth arrest: Influence of cell-cycle position, p53, p21 and bax in $\mathrm{H}_{2} \mathrm{O}_{2}$ response of normal human fibroblasts. Biochem. J. 2000, 347, 543-551. [CrossRef]

22. Hampel, B.; Malisan, F.; Niederegger, H.; Testi, R.; Jansen-Dürr, P. Differential regulation of apoptotic cell death in senescent human cells. Exp. Gerontol. 2004, 39, 1713-1721. [CrossRef] [PubMed]

23. Narita, M.; Nuñez, S.; Heard, E.; Narita, M.; Lin, A.W.; Hearn, S.A.; Spector, D.L.; Hannon, G.J.; Lowe, S.W. Rb-mediated heterochromatin formation and silencing of E2F target genes during cellular senescence. Cell 2003, 113, 703-716. [CrossRef]

24. Narita, M.; Narita, M.; Krizhanovsky, V.; Nuñez, S.; Chicas, A.; Hearn, S.A.; Myers, P.M.; Lowe, S.W. A novel role for high-mobility group a proteins in cellular senescence and heterochromatin formation. Cell 2006, 126, 503-514. [CrossRef]

25. Shimi, T.; Butin-Israeli, V.; Adam, S.A.; Hamanaka, R.B.; Goldman, A.E.; Lucas, C.A.; Shumaker, D.K.; Kosak, S.T.; Chandel, N.S.; Goldman, R.D. The role of nuclear lamin B1 in cell proliferation and senescence. Genes Dev. 2011, 25, 2579-2593. [CrossRef]

26. Matias, I.; Diniz, L.P.; Damico, I.V.; Araujo, A.P.B.; Neves, L.D.S.; Vargas, G.; Leite, R.E.P.; Suemoto, C.K.; Nitrini, R.; Jacob-Filho, W.; et al. Loss of lamin-B1 and defective nuclear morphology are hallmarks of astrocyte senescence in vitro and in the aging human hippocampus. Aging Cell 2021, 21, e13521. [CrossRef]

27. Pathak, R.U.; Soujanya, M.; Mishra, R.K. Deterioration of nuclear morphology and architecture: A hallmark of senescence and aging. Ageing Res. Rev. 2021, 67, 101264. [CrossRef]

28. Oberdoerffer, P.; Sinclair, D. The role of nuclear architecture in genomic instability and ageing. Nat. Rev. Mol. Cell Biol. 2007, 8 , 692-702. [CrossRef] [PubMed]

29. Lopatina, N.; Haskell, J.F.; Andrews, L.G.; Poole, J.C.; Saldanha, S.; Tollefsbol, T. Differential maintenance and de novo methylating activity by three DNA methyltransferases in aging and immortalized fibroblasts. J. Cell. Biochem. 2002, 84, 324-334. [CrossRef] [PubMed]

30. Coppé, J.-P.; Desprez, P.-Y.; Krtolica, A.; Campisi, J. The Senescence-Associated Secretory Phenotype: The Dark Side of Tumor Suppression. Annu. Rev. Pathol. Mech. Dis. 2010, 5, 99-118. [CrossRef]

31. Nacarelli, T.; Liu, P.; Zhang, R. Epigenetic Basis of Cellular Senescence and Its Implications in Aging. Genes 2017, 8, 343. [CrossRef] [PubMed]

32. Sidler, C.; Kovalchuk, O.; Kovalchuk, I. Epigenetic Regulation of Cellular Senescence and Aging. Front. Genet. 2017, 8, 138. [CrossRef] [PubMed]

33. Wang, T.; Notta, F.; Navab, R.; Joseph, J.; Ibrahimov, E.; Xu, J.; Zhu, C.-Q.; Borgida, A.; Gallinger, S.; Tsao, M.-S. Senescent Carcinoma-associated Fibroblasts Upregulate IL8 to Enhance Prometastatic Phenotypes. Mol. Cancer Res. 2016, 15, 3-14. [CrossRef] [PubMed]

34. Kehrl, J.; Wakefield, L.M.; Roberts, A.B.; Jakowlew, S.; Alvarez-Mon, M.; Derynck, R.; Sporn, M.B.; Fauci, A.S. Production of transforming growth factor beta by human $\mathrm{T}$ lymphocytes and its potential role in the regulation of T cell growth. J. Exp. Med. 1986, 163, 1037-1050. [CrossRef]

35. Hoare, M.; Ito, Y.; Kang, T.W.; Weekes, M.P.; Matheson, N.J.; Patten, D.A.; Shetty, S.; Parry, A.J.; Menon, S.; Salama, R.; et al NOTCH1 mediates a switch between two distinct secretomes during senescence. Nat. Cell Biol. 2016, 18, 979-992. [CrossRef]

36. Acosta, J.C.; Banito, A.; Wuestefeld, T.; Georgilis, A.; Janich, P.; Morton, J.P.; Athineos, D.; Kang, T.-W.; Lasitschka, F.; Andrulis, M.; et al. A complex secretory program orchestrated by the inflammasome controls paracrine senescence. Nat. Cell Biol. 2013, 15, 978-990. [CrossRef]

37. van Deursen, J.M. The role of senescent cells in ageing. Nature 2014, 509, 439-446. [CrossRef]

38. Minamino, T.; Miyauchi, H.; Yoshida, T.; Komuro, I. Endothelial cell senescence in human atherosclerosis: Role of telomeres in endothelial dysfunction. J. Cardiol. 2003, 41, 1541-1544. [CrossRef]

39. Schroth, J.; Thiemermann, C.; Henson, S.M. Senescence and the Aging Immune System as Major Drivers of Chronic Kidney Disease. Front. Cell Dev. Biol. 2020, 8, 564461. [CrossRef]

40. Ogrodnik, M.; Miwa, S.; Tchkonia, T.; Tiniakos, D.; Wilson, C.L.; Lahat, A.; Day, C.P.; Burt, A.; Palmer, A.; Anstee, Q.M.; et al. Cellular senescence drives age-dependent hepatic steatosis. Nat. Commun. 2017, 8, 15691. [CrossRef]

41. Jeyapalan, J.C.; Ferreira, M.; Sedivy, J.M.; Herbig, U. Accumulation of senescent cells in mitotic tissue of aging primates. Mech Ageing Dev. 2007, 128, 36-44. [CrossRef] [PubMed]

42. Krishnamurthy, J.; Ramsey, M.; Ligon, K.L.; Torrice, C.; Koh, A.; Bonner-Weir, S.; Sharpless, N. p16INK4a induces an agedependent decline in islet regenerative potential. Nature 2006, 443, 453-457. [CrossRef]

43. Molofsky, A.V.; Slutsky, S.G.; Joseph, N.M.; He, S.; Pardal, R.; Krishnamurthy, J.; Sharpless, N.; Morrison, S.J. Increasing p16INK4a expression decreases forebrain progenitors and neurogenesis during ageing. Nature 2006, 443, 448-452. [CrossRef] [PubMed]

44. Sharma, R.; Ramanathan, A. The Aging Metabolome-Biomarkers to Hub Metabolites. Proteomics 2020, 20, e1800407. [CrossRef] [PubMed]

45. Gao, W.; Liu, J.-L.; Lu, X.; Yang, Q. Epigenetic regulation of energy metabolism in obesity. J. Mol. Cell Biol. 2021, 13, 480-499. [CrossRef]

46. Matilainen, O.; Quiros, P.M.; Auwerx, J. Mitochondria and Epigenetics-Crosstalk in Homeostasis and Stress. Trends Cell Biol. 2017, 27, 453-463. [CrossRef] 
47. Schell, J.C.; Rutter, J. Mitochondria link metabolism and epigenetics in haematopoiesis. Nat. Cell Biol. 2017, 19, 589-591. [CrossRef]

48. Zhu, X.; Chen, Z.; Shen, W.; Huang, G.; Sedivy, J.M.; Wang, H.; Ju, Z. Inflammation, epigenetics, and metabolism converge to cell senescence and ageing: The regulation and intervention. Signal Transduct. Target. Ther. 2021, 6, 1-29. [CrossRef]

49. Minocherhomji, S.; Tollefsbol, T.O.; Singh, K.K. Mitochondrial regulation of epigenetics and its role in human diseases. Epigenetics 2012, 7, 326-334. [CrossRef]

50. Grewal, S.I.S.; Moazed, D. Heterochromatin and Epigenetic Control of Gene Expression. Science 2003, 301, 798-802. [CrossRef]

51. Smeal, T.; Claus, J.; Kennedy, B.; Cole, F.; Guarente, L. Loss of Transcriptional Silencing Causes Sterility in Old Mother Cells of S. cerevisiae. Cell 1996, 84, 633-642. [CrossRef]

52. Villeponteau, B. The heterochromatin loss model of aging. Exp. Gerontol. 1997, 32, 383-394. [CrossRef]

53. Haithcock, E.; Dayani, Y.; Neufeld, E.; Zahand, A.J.; Feinstein, N.; Mattout, A.; Gruenbaum, Y.; Liu, J. Age-related changes of nuclear architecture in Caenorhabditis elegans. Proc. Natl. Acad. Sci. USA 2005, 102, 16690-16695. [CrossRef] [PubMed]

54. Larson, K.; Yan, S.-J.; Tsurumi, A.; Liu, J.; Zhou, J.; Gaur, K.; Guo, D.; Eickbush, T.H.; Li, W.X. Heterochromatin Formation Promotes Longevity and Represses Ribosomal RNA Synthesis. PLoS Genet. 2012, 8, e1002473. [CrossRef]

55. Zhang, W.; Li, J.; Suzuki, K.; Qu, J.; Wang, P.; Zhou, J.; Liu, X.; Ren, R.; Xu, X.; Ocampo, A.; et al. A Werner syndrome stem cell model unveils heterochromatin alterations as a driver of human aging. Science 2015, 348, 1160-1163. [CrossRef]

56. Goldman, R.D.; Shumaker, D.K.; Erdos, M.R.; Eriksson, M.; Goldman, A.E.; Gordon, L.B.; Gruenbaum, Y.; Khuon, S.; Mendez, M.; Varga, R.; et al. Accumulation of mutant lamin A causes progressive changes in nuclear architecture in Hutchinson-Gilford progeria syndrome. Proc. Natl. Acad. Sci. USA 2004, 101, 8963-8968. [CrossRef]

57. O'Sullivan, R.J.; Kubicek, S.; Schreiber, S.L.; Karlseder, J. Reduced histone biosynthesis and chromatin changes arising from a damage signal at telomeres. Nat. Struct. Mol. Biol. 2010, 17, 1218-1225. [CrossRef]

58. Ivanov, A.; Pawlikowski, J.; Manoharan, I.; Van Tuyn, J.; Nelson, D.M.; Rai, T.S.; Shah, P.P.; Hewitt, G.; Korolchuk, V.; Passos, J.; et al. Lysosome-mediated processing of chromatin in senescence. J. Cell Biol. 2013, 202, 129-143. [CrossRef]

59. Bannister, A.J.; Kouzarides, T. Regulation of chromatin by histone modifications. Cell Res. 2011, 21, 381-395. [CrossRef]

60. Jambhekar, A.; Dhall, A.; Shi, Y. Roles and regulation of histone methylation in animal development. Nat. Rev. Mol. Cell Biol. 2019, 20, 625-641. [CrossRef]

61. Lessard, J.; Sauvageau, G. Bmi-1 determines the proliferative capacity of normal and leukaemic stem cells. Nature 2003, 423 , 255-260. [CrossRef] [PubMed]

62. Jacobs, J.; Kieboom, K.; Marino, S.; DePinho, R.; Van Lohuizen, M. The oncogene and Polycomb-group gene bmi-1 regulates cell proliferation and senescence through the ink4a locus. Nature 1999, 397, 164-168. [CrossRef] [PubMed]

63. Beà, S.; Tort, F.; Pinyol, M.; Puig, X.; Hernández, L.; Hernández, S.; Fernandez, P.L.; Van Lohuizen, M.; Colomer, D.; Campo, E BMI-1 gene amplification and overexpression in hematological malignancies occur mainly in mantle cell lymphomas. Cancer Res. 2001, 61, 2409-2412. [PubMed]

64. Vonlanthen, S.; Heighway, J.; Altermatt, H.J.; Gugger, M.; Kappeler, A.; Borner, M.M.; Van Lohuizen, M.; Betticher, D.C. The bmi-1 oncoprotein is differentially expressed in non-small cell lung cancer and correlates with INK4A-ARF locus expression. Br. J. Cancer 2001, 84, 1372-1376. [CrossRef] [PubMed]

65. Kim, J.H.; Yoon, S.Y.; Kim, C.N.; Joo, J.H.; Moon, S.K.; Choe, I.S.; Choe, Y.K.; Kim, J.W. The Bmi-1 oncoprotein is overexpressed in human colorectal cancer and correlates with the reduced p16INK4a/p14ARF proteins. Cancer Lett. 2004, 203, 217-224. [CrossRef] [PubMed]

66. Neo, S.Y.; Leow, C.K.; Vega, V.B.; Long, P.M.; Islam, A.F.; Lai, P.B.; Liu, E.T.; Ren, E.C. Identification of discriminators of hepatoma by gene expression profiling using a minimal dataset approach. Hepatology 2004, 39, 944-953. [CrossRef]

67. Gil, J.; Bernard, D.; Martínez, D.; Beach, D. Polycomb CBX7 has a unifying role in cellular lifespan. Nat. Cell Biol. 2003, 6, 67-72. [CrossRef]

68. Itahana, K.; Zou, Y.; Itahana, Y.; Martinez-Guitarte, J.-L.; Beausejour, C.; Jacobs, J.; van Lohuizen, M.; Band, V.; Campisi, J.; Dimri, G.P. Control of the Replicative Life Span of Human Fibroblasts by p16 and the Polycomb Protein Bmi-1. Mol. Cell. Biol. 2003, 23, 389-401. [CrossRef]

69. Guo, W.-J.; Datta, S.; Band, V.; Dimri, G.P. Mel-18, a Polycomb Group Protein, Regulates Cell Proliferation and Senescence via Transcriptional Repression of Bmi-1 and c-Myc Oncoproteins. Mol. Biol. Cell 2007, 18, 536-546. [CrossRef]

70. Kim, M.K.; Nikodem, V.M. hnRNP U Inhibits Carboxy-Terminal Domain Phosphorylation by TFIIH and Represses RNA Polymerase II Elongation. Mol. Cell. Biol. 1999, 19, 6833-6844. [CrossRef]

71. Weidensdorfer, D.; Stöhr, N.; Baude, A.; Lederer, M.; Köhn, M.; Schierhorn, A.; Buchmeier, S.; Wahle, E.; Hüttelmaier, S. Control of c-myc mRNA stability by IGF2BP1-associated cytoplasmic RNPs. RNA 2008, 15, 104-115. [CrossRef] [PubMed]

72. Nozawa, R.-S.; Boteva, L.; Soares, D.; Naughton, C.; Dun, A.R.; Buckle, A.; Ramsahoye, B.; Bruton, P.C.; Saleeb, R.S.; Arnedo, M.; et al. SAF-A Regulates Interphase Chromosome Structure through Oligomerization with Chromatin-Associated RNAs. Cell 2017, 169, 1214-1227.e18. [CrossRef]

73. Puvvula, P.K.; Desetty, R.D.; Pineau, P.; Marchio, A.; Moon, A.; Dejean, A.; Bischof, O. Long noncoding RNA PANDA and scaffold-attachment-factor SAFA control senescence entry and exit. Nat. Commun. 2014, 5, 5323. [CrossRef] [PubMed]

74. Puvvula, P.K. LncRNAs Regulatory Networks in Cellular Senescence. Int. J. Mol. Sci. 2019, 20, 2615. [CrossRef]

75. Suh, N. MicroRNA controls of cellular senescence. BMB Rep. 2018, 51, 493-499. [CrossRef]

76. Kim, E.; Kim, Y.K.; Lee, S.-J.V. Emerging functions of circular RNA in aging. Trends Genet. 2021, 37, 819-829. [CrossRef] [PubMed] 
77. Schumacher, A.; Faust, C.; Magnuson, T. Positional cloning of a global regulator of anterior-posterior patterning in mice. Nature 1996, 383, 250-253. [CrossRef]

78. Ito, T.; Teo, Y.V.; Evans, S.A.; Neretti, N.; Sedivy, J.M. Regulation of Cellular Senescence by Polycomb Chromatin Modifiers through Distinct DNA Damage- and Histone Methylation-Dependent Pathways. Cell Rep. 2018, 22, 3480-3492. [CrossRef]

79. Barradas, M.; Anderton, E.; Acosta, J.C.; Li, S.; Banito, A.; Rodriguez-Niedenführ, M.; Maertens, G.; Banck, M.; Zhou, M.-M.; Walsh, M.J.; et al. Histone demethylase JMJD3 contributes to epigenetic control of INK4a/ARF by oncogenic RAS. Genes Dev. 2009, 23, 1177-1182. [CrossRef]

80. Wang, Z.; Qin, G.; Zhao, T.C. HDAC4: Mechanism of regulation and biological functions. Epigenomics 2014, 6, 139-150. [CrossRef]

81. Di Giorgio, E.; Dalla, E.; Franforte, E.; Paluvai, H.; Minisini, M.; Trevisanut, M.; Picco, R.; Brancolini, C. Different class IIa HDACs repressive complexes regulate specific epigenetic responses related to cell survival in leiomyosarcoma cells. Nucleic Acids Res. 2020, 48, 646-664. [CrossRef] [PubMed]

82. Di Giorgio, E.; Paluvai, H.; Dalla, E.; Ranzino, L.; Renzini, A.; Moresi, V.; Minisini, M.; Picco, R.; Brancolini, C. HDAC4 degradation during senescence unleashes an epigenetic program driven by AP-1/p300 at selected enhancers and super-enhancers. Genome Biol. 2021, 22, 1-25. [CrossRef]

83. Sen, P.; Lan, Y.; Li, C.Y.; Sidoli, S.; Donahue, G.; Dou, Z.; Frederick, B.; Chen, Q.; Luense, L.J.; Garcia, B.A.; et al. Histone Acetyltransferase p300 Induces De Novo Super-Enhancers to Drive Cellular Senescence. Mol. Cell 2019, 73, 684-698.e8. [CrossRef] [PubMed]

84. Chandra, T.; Kirschner, K.; Thuret, J.-Y.; Pope, B.; Ryba, T.; Newman, S.; Ahmed, K.; Samarajiwa, S.; Salama, R.; Carroll, T.; et al. Independence of Repressive Histone Marks and Chromatin Compaction during Senescent Heterochromatic Layer Formation Mol. Cell 2012, 47, 203-214. [CrossRef]

85. Funayama, R.; Saito, M.; Tanobe, H.; Ishikawa, F. Loss of linker histone H1 in cellular senescence. J. Cell Biol. 2006, 175, 869-880. [CrossRef] [PubMed]

86. Braig, M.; Lee, S.; Loddenkemper, C.; Rudolph, C.; Peters, A.H.; Schlegelberger, B.; Stein, H.; Dörken, B.; Jenuwein, T.; Schmitt, C.A. Oncogene-induced senescence as an initial barrier in lymphoma development. Nature 2005, 436, 660-665. [CrossRef]

87. Kovatcheva, M.; Liao, W.; Klein, M.E.; Robine, N.; Geiger, H.; Crago, A.M.; Dickson, M.A.; Tap, W.D.; Singer, S.; Koff, A. ATRX is a regulator of therapy induced senescence in human cells. Nat. Commun. 2017, 8, 386. [CrossRef]

88. Zhang, Y.; Gao, Y.; Zhao, L.; Han, L.; Lu, Y.; Hou, P.; Shi, X.; Liu, X.; Tian, B.; Wang, X.; et al. Mitogen-activated protein kinase p38 and retinoblastoma protein signalling is required for DNA damage-mediated formation of senescence-associated heterochromatic foci in tumour cells. FEBS J. 2013, 280, 4625-4639. [CrossRef]

89. Zhao, L.; Zhang, Y.; Gao, Y.; Geng, P.; Lu, Y.; Liu, X.; Yao, R.; Hou, P.; Liu, D.; Lu, J.; et al. JMJD3 promotes SAHF formation in senescent WI38 cells by triggering an interplay between demethylation and phosphorylation of RB protein. Cell Death Differ. 2015, 22, 1630-1640. [CrossRef]

90. Košař, M.; Bartkova, J.; Hubackova, S.; Hodny, Z.; Lukas, J.; Bartek, J. Senescence-associated heterochromatin foci are dispensable for cellular senescence, occur in a cell type- and insult-dependent manner and follow expression of p16 ink4a. Cell Cycle 2011, 10, 457-468. [CrossRef] [PubMed]

91. Henikoff, S.; Smith, M.M. Histone Variants and Epigenetics. Cold Spring Harb. Perspect. Biol. 2015, 7, a019364. [CrossRef]

92. Duarte, L.F.; Young, A.; Wang, Z.; Wu, H.-A.; Panda, T.; Kou, Y.; Kapoor, A.; Hasson, D.; Mills, N.R.; Ma'Ayan, A.; et al. Histone H3.3 and its proteolytically processed form drive a cellular senescence programme. Nat. Commun. 2014, 5, 5210. [CrossRef] [PubMed]

93. Rai, T.S.; Cole, J.J.; Nelson, D.M.; Dikovskaya, D.; Faller, W.J.; Vizioli, M.G.; Hewitt, R.N.; Anannya, O.; McBryan, T.; Manoharan, I.; et al. HIRA orchestrates a dynamic chromatin landscape in senescence and is required for suppression of neoplasia. Genes Dev. 2014, 28, 2712-2725. [CrossRef] [PubMed]

94. Zhang, R.; Poustovoitov, M.V.; Ye, X.; Santos, H.A.; Chen, W.; Daganzo, S.M.; Erzberger, J.P.; Serebriiskii, I.G.; Canutescu, A.A.; Dunbrack, R.; et al. Formation of MacroH2A-Containing Senescence-Associated Heterochromatin Foci and Senescence Driven by ASF1a and HIRA. Dev. Cell 2005, 8, 19-30. [CrossRef]

95. Contrepois, K.; Coudereau, C.; Benayoun, B.A.; Schuler, N.; Roux, P.-F.; Bischof, O.; Courbeyrette, R.; Carvalho, C.; Thuret, J.-Y.; $\mathrm{Ma}, \mathrm{Z} . ;$ et al. Histone variant H2A.J accumulates in senescent cells and promotes inflammatory gene expression. Nat. Commun. 2017, 8, 14995. [CrossRef] [PubMed]

96. Gévry, N.; Chan, H.M.; Laflamme, L.; Livingston, D.M.; Gaudreau, L. p21 transcription is regulated by differential localization of histone H2A.Z. Genes Dev. 2007, 21, 1869-1881. [CrossRef]

97. Hovest, M.G.; Brüggenolte, N.; Hosseini, K.S.; Krieg, T.; Herrmann, G. Senescence of Human Fibroblasts after Psoralen Photoactivation Is Mediated by ATR Kinase and Persistent DNA Damage Foci at Telomeres. Mol. Biol. Cell 2006, 17, $1758-1767$. [CrossRef] [PubMed]

98. Cruickshanks, H.A.; McBryan, T.; Nelson, D.M.; VanderKraats, N.D.; Shah, P.P.; Van Tuyn, J.; Rai, T.S.; Brock, C.; Donahue, G.; Dunican, D.S.; et al. Senescent cells harbour features of the cancer epigenome. Nat. Cell Biol. 2013, 15, 1495-1506. [CrossRef]

99. Sakaki, M.; Ebihara, Y.; Okamura, K.; Nakabayashi, K.; Igarashi, A.; Matsumoto, K.; Hata, K.; Kobayashi, Y.; Maehara, K. Potential roles of DNA methylation in the initiation and establishment of replicative senescence revealed by array-based methylome and transcriptome analyses. PLoS ONE 2017, 12, e0171431. [CrossRef] 
100. Arand, J.; Spieler, D.; Karius, T.; Branco, M.R.; Meilinger, D.; Meissner, A.; Jenuwein, T.; Xu, G.; Leonhardt, H.; Wolf, V.; et al. In Vivo Control of CpG and Non-CpG DNA Methylation by DNA Methyltransferases. PLoS Genet. 2012, 8, e1002750. [CrossRef]

101. Scott-Browne, J.P.; Lio, C.-W.J.; Rao, A. TET proteins in natural and induced differentiation. Curr. Opin. Genet. Dev. 2017, 46, 202-208. [CrossRef] [PubMed]

102. Parry, A.; Rulands, S.; Reik, W. Active turnover of DNA methylation during cell fate decisions. Nat. Rev. Genet. 2021, $22,59-66$. [CrossRef] [PubMed]

103. Xu, G.-L.; Bochtler, M. Reversal of nucleobase methylation by dioxygenases. Nat. Chem. Biol. 2020, 16, 1160-1169. [CrossRef] [PubMed]

104. Lio, C.-W.J.; Yue, X.; Lopez-Moyado, I.F.; Tahiliani, M.; Aravind, L.; Rao, A. TET methylcytosine oxidases: New insights from a decade of research. J. Biosci. 2020, 45, 21. [CrossRef]

105. Rinaldi, L.; Datta, D.; Serrat, J.; Morey, L.; Solanas, G.; Avgustinova, A.; Blanco, E.; Pons, J.I.; Matallanas, D.; von Kriegsheim, A.; et al. Dnmt3a and Dnmt3b Associate with Enhancers to Regulate Human Epidermal Stem Cell Homeostasis. Cell Stem Cell 2016, 19, 491-501. [CrossRef]

106. Liu, L.; Wang, H.; Xu, G.; Liu, L. Tet1 Deficiency Leads to Premature Ovarian Failure. Front. Cell Dev. Biol. 2021, 9, 620. [CrossRef]

107. Huang, G.; Liu, L.; Wang, H.; Gou, M.; Gong, P.; Tian, C.; Deng, W.; Yang, J.; Zhou, T.-T.; Xu, G.-L.; et al. Tet1 Deficiency Leads to Premature Reproductive Aging by Reducing Spermatogonia Stem Cells and Germ Cell Differentiation. IScience 2020, $23,100908$. [CrossRef]

108. Ferrone, C.K.; Blydt-Hansen, M.; Rauh, M.J. Age-Associated TET2 Mutations: Common Drivers of Myeloid Dysfunction, Cancer and Cardiovascular Disease. Int. J. Mol. Sci. 2020, 21, 626. [CrossRef]

109. Weidner, C.I.; Lin, Q.; Koch, C.M.; Eisele, L.; Beier, F.; Ziegler, P.; Bauerschlag, D.O.; Jöckel, K.-H.; Erbel, R.; Mühleisen, T.W.; et al. Aging of blood can be tracked by DNA methylation changes at just three CpG sites. Genome Biol. 2014, 15, R24. [CrossRef] [PubMed]

110. Meer, M.V.; Podolskiy, D.I.; Tyshkovskiy, A.; Gladyshev, V.N. A whole lifespan mouse multi-tissue DNA methylation clock. Elife 2018, 7, 7. [CrossRef]

111. Koch, C.M.; Joussen, S.; Schellenberg, A.; Lin, Q.; Zenke, M.; Wagner, W. Monitoring of cellular senescence by DNA-methylation at specific CpG sites. Aging Cell 2012, 11, 366-369. [CrossRef] [PubMed]

112. Bork, S.; Pfister, S.; Witt, H.; Horn, P.; Korn, B.; Ho, A.D.; Wagner, W. DNA methylation pattern changes upon long-term culture and aging of human mesenchymal stromal cells. Aging Cell 2010, 9, 54-63. [CrossRef] [PubMed]

113. Ting, A.H.; McGarvey, K.M.; Baylin, S.B. The cancer epigenome-components and functional correlates. Genes Dev. 2006, 20, 3215-3231. [CrossRef] [PubMed]

114. Xie, W.; Kagiampakis, I.; Pan, L.; Zhang, Y.W.; Murphy, L.; Tao, Y.; Kong, X.; Kang, B.; Xia, L.; Carvalho, F.L.; et al. DNA Methylation Patterns Separate Senescence from Transformation Potential and Indicate Cancer Risk. Cancer Cell 2018, 33, 309321.e5. [CrossRef]

115. Sarkar, T.J.; Quarta, M.; Mukherjee, S.; Colville, A.; Paine, P.; Doan, L.; Tran, C.M.; Chu, C.R.; Horvath, S.; Qi, L.S.; et al. Transient non-integrative expression of nuclear reprogramming factors promotes multifaceted amelioration of aging in human cells. Nat. Commun. 2020, 11, 1545. [CrossRef]

116. Lapasset, L.; Milhavet, O.; Prieur, A.; Besnard, E.; Babled, A.; Aït-Hamou, N.; Leschik, J.; Pellestor, F.; Ramirez, J.-M.; De Vos, J.; et al. Rejuvenating senescent and centenarian human cells by reprogramming through the pluripotent state. Genes Dev. 2011, 25, 2248-2253. [CrossRef]

117. Ocampo, A.; Reddy, P.; Redondo, P.M.; Luengo, A.P.; Hatanaka, F.; Hishida, T.; Li, M.; Lam, D.; Kurita, M.; Beyret, E.; et al. In Vivo Amelioration of Age-Associated Hallmarks by Partial Reprogramming. Cell 2016, 167, 1719-1733.e12. [CrossRef]

118. Lu, Y.; Brommer, B.; Tian, X.; Krishnan, A.; Meer, M.; Wang, C.; Vera, D.L.; Zeng, Q.; Yu, D.; Bonkowski, M.S.; et al. Reprogramming to recover youthful epigenetic information and restore vision. Nature 2020, 588, 124-129. [CrossRef]

119. Voong, C.K.; Goodrich, J.A.; Kugel, J.F. Interactions of HMGB Proteins with the Genome and the Impact on Disease. Biomolecules 2021, 11, 1451. [CrossRef]

120. Aird, K.M.; Iwasaki, O.; Kossenkov, A.V.; Tanizawa, H.; Fatkhutdinov, N.; Bitler, B.; Le, L.; Alicea, G.; Yang, T.-L.; Johnson, F.B.; et al. HMGB2 orchestrates the chromatin landscape of senescence-associated secretory phenotype gene loci. J. Cell Biol. 2016, 215, 325-334. [CrossRef]

121. Tasdemir, N.; Banito, A.; Roe, J.-S.; Curbelo, D.A.; Camiolo, M.; Tschaharganeh, D.F.; Huang, C.-H.; Aksoy, O.; Bolden, J.E.; Chen, C.-C.; et al. BRD4 Connects Enhancer Remodeling to Senescence Immune Surveillance. Cancer Discov. 2016, 6, 612-629. [CrossRef] [PubMed]

122. Capell, B.C.; Drake, A.M.; Zhu, J.; Shah, P.P.; Dou, Z.; Dorsey, J.; Simola, D.F.; Donahue, G.; Sammons, M.; Rai, T.S.; et al. MLL1 is essential for the senescence-associated secretory phenotype. Genes Dev. 2016, 30, 321-336. [CrossRef] [PubMed]

123. Leon, K.E.; Buj, R.; Lesko, E.; Dahl, E.S.; Chen, C.-W.; Tangudu, N.K.; Kawasawa, Y.I.; Kossenkov, A.V.; Hobbs, R.P.; Aird, K.M. DOT1L modulates the senescence-associated secretory phenotype through epigenetic regulation of IL1A. J. Cell Biol. 2021, 220, 202008101. [CrossRef] [PubMed]

124. Takahashi, A.; Imai, Y.; Yamakoshi, K.; Kuninaka, S.; Ohtani, N.; Yoshimoto, S.; Hori, S.; Tachibana, M.; Anderton, E.; Takeuchi, T.; et al. DNA Damage Signaling Triggers Degradation of Histone Methyltransferases through APC/CCdh1 in Senescent Cells. Mol. Cell 2012, 45, 123-131. [CrossRef] [PubMed] 
125. Perrigue, P.M.; Silva, M.E.; Warden, C.D.; Feng, N.L.; Reid, M.; Mota, D.J.; Joseph, L.P.; Tian, Y.I.; Glackin, C.A.; Gutova, M.; et al. The Histone Demethylase Jumonji Coordinates Cellular Senescence Including Secretion of Neural Stem Cell-Attracting Cytokines. Mol. Cancer Res. 2015, 13, 636-650. [CrossRef]

126. Hayakawa, T.; Iwai, M.; Aoki, S.; Takimoto, K.; Maruyama, M.; Maruyama, W.; Motoyama, N. SIRT1 Suppresses the SenescenceAssociated Secretory Phenotype through Epigenetic Gene Regulation. PLoS ONE 2015, 10, e0116480. [CrossRef] [PubMed]

127. Pospelova, T.V.; Demidenko, Z.N.; Bukreeva, E.I.; Pospelov, V.A.; Gudkov, A.; Blagosklonny, M.V. Pseudo-DNA damage response in senescent cells. Cell Cycle 2009, 8, 4112-4118. [CrossRef]

128. Pazolli, E.; Alspach, E.; Milczarek, A.; Prior, J.; Piwnica-Worms, D.; Stewart, S.A. Chromatin Remodeling Underlies the SenescenceAssociated Secretory Phenotype of Tumor Stromal Fibroblasts That Supports Cancer Progression. Cancer Res. 2012, 72, 2251-2261. [CrossRef]

129. Barger, J.L.; Kayo, T.; Vann, J.M.; Arias, E.B.; Wang, J.; Hacker, T.A.; Wang, Y.; Raederstorff, D.; Morrow, J.D.; Leeuwenburgh, C.; et al. A low dose of dietary resveratrol partially mimics caloric restriction and retards aging parameters in mice. PLOS ONE 2008, 3, e2264. [CrossRef]

130. Fischer-Posovszky, P.; Kukulus, V.; Tews, D.; Unterkircher, T.; Debatin, K.-M.; Fulda, S.; Wabitsch, M. Resveratrol regulates human adipocyte number and function in a Sirt1-dependent manner. Am. J. Clin. Nutr. 2010, 92, 5-15. [CrossRef]

131. Subramanian, L.; Youssef, S.; Bhattacharya, S.; Kenealey, J.; Polans, A.S.; van Ginkel, P.R. Resveratrol: Challenges in translation to the clinic-a critical discussion. Clin. Cancer Res. 2010, 16, 5942-5948. [CrossRef] [PubMed]

132. Wiley, J.C.; Pettan-Brewer, C.; Ladiges, W.C. Phenylbutyric acid reduces amyloid plaques and rescues cognitive behavior in AD transgenic mice. Aging Cell 2011, 10, 418-428. [CrossRef]

133. Yoo, Y.-E.; Ko, C.-P. Treatment with trichostatin A initiated after disease onset delays disease progression and increases survival in a mouse model of amyotrophic lateral sclerosis. Exp. Neurol. 2011, 231, 147-159. [CrossRef] [PubMed]

134. Harrison, I.F.; Crum, W.R.; Vernon, A.C.; Dexter, D.T. Neurorestoration induced by the HDAC inhibitor sodium valproate in the lactacystin model of P arkinson's is associated with histone acetylation and up-regulation of neurotrophic factors. Br. J. Pharmacol. 2015, 172, 4200-4215. [CrossRef]

135. Gao, Z.; Yin, J.; Zhang, J.; Ward, R.E.; Martin, R.J.; Lefevre, M.; Cefalu, W.T.; Ye, J. Butyrate Improves Insulin Sensitivity and Increases Energy Expenditure in Mice. Diabetes 2009, 58, 1509-1517. [CrossRef] [PubMed]

136. Henagan, T.M.; Stefanska, B.; Fang, Z.; Navard, A.M.; Ye, J.; Lenard, N.R.; Devarshi, P. Sodium butyrate epigenetically modulates high-fat diet-induced skeletal muscle mitochondrial adaptation, obesity and insulin resistance through nucleosome positioning. $J$. Cereb. Blood Flow Metab. 2015, 172, 2782-2798. [CrossRef]

137. Piekarz, R.L.; Frye, R.; Turner, M.; Wright, J.J.; Allen, S.; Kirschbaum, M.H.; Zain, J.; Prince, H.M.; Leonard, J.P.; Geskin, L.J.; et al. Phase II Multi-Institutional Trial of the Histone Deacetylase Inhibitor Romidepsin As Monotherapy for Patients with Cutaneous T-Cell Lymphoma. J. Clin. Oncol. 2009, 27, 5410-5417. [CrossRef]

138. Whittaker, S.J.; Demierre, M.-F.; Kim, E.J.; Rook, A.H.; Lerner, A.; Duvic, M.; Scarisbrick, J.; Reddy, S.; Robak, T.; Becker, J.C.; et al. Final Results from a Multicenter, International, Pivotal Study of Romidepsin in Refractory Cutaneous T-Cell Lymphoma. J. Clin. Oncol. 2010, 28, 4485-4491. [CrossRef]

139. Coiffier, B.; Pro, B.; Prince, H.M.; Foss, F.; Sokol, L.; Greenwood, M.; Caballero, D.; Borchmann, P.; Morschhauser, F.; Wilhelm, M.; et al. Results from a Pivotal, Open-Label, Phase II Study of Romidepsin in Relapsed or Refractory Peripheral T-Cell Lymphoma After Prior Systemic Therapy. J. Clin. Oncol. 2012, 30, 631-636. [CrossRef]

140. O'Connor, O.A.; Horwitz, S.; Masszi, T.; Van Hoof, A.; Brown, P.D.N.; Doorduijn, J.; Hess, G.; Jurczak, W.; Knoblauch, P.; Chawla, S.; et al. Belinostat in Patients with Relapsed or Refractory Peripheral T-Cell Lymphoma: Results of the Pivotal Phase II BELIEF (CLN-19) Study. J. Clin. Oncol. 2015, 33, 2492-2499. [CrossRef]

141. Derissen, E.J.; Beijnen, J.H.; Schellens, J.H. Concise Drug Review: Azacitidine and Decitabine. Oncologist 2013, 18, 619-624. [CrossRef] [PubMed]

142. Italiano, A.; Soria, J.C.; Toulmonde, M.; Michot, J.M.; Lucchesi, C.; Varga, A.; Coindre, J.M.; Blakemore, S.J.; Clawson, A.; Suttle, B.; et al. Tazemetostat, an EZH2 inhibitor, in relapsed or refractory B-cell non-Hodgkin lymphoma and advanced solid tumours: A first-in-human, open-label, phase 1 study. Lancet Oncol. 2018, 19, 649-659. [CrossRef]

143. Thomas, S.; Thurn, K.T.; Biçaku, E.; Marchion, D.C.; Münster, P.N. Addition of a histone deacetylase inhibitor redirects tamoxifentreated breast cancer cells into apoptosis, which is opposed by the induction of autophagy. Breast Cancer Res. Treat. 2011, 130, 437-447. [CrossRef] [PubMed]

144. Hodges-Gallagher, L.; Valentine, C.D.; El Bader, S.; Kushner, P.J. Inhibition of histone deacetylase enhances the anti-proliferative action of antiestrogens on breast cancer cells and blocks tamoxifen-induced proliferation of uterine cells. Breast Cancer Res. Treat. 2006, 105, 297-309. [CrossRef] [PubMed]

145. Morel, D.; Jeffery, D.; Aspeslagh, S.; Almouzni, G.; Postel-Vinay, S. Combining epigenetic drugs with other therapies for solid tumours-Past lessons and future promise. Nat. Rev. Clin. Oncol. 2020, 17, 91-107. [CrossRef] [PubMed]

146. Pasyukova, E.G.; Vaiserman, A.M. HDAC inhibitors: A new promising drug class in anti-aging research. Mech. Ageing Dev. 2017, 166, 6-15. [CrossRef] [PubMed]

147. De Lera, A.R.; Ganesan, A. Two-hit wonders: The expanding universe of multitargeting epigenetic agents. Curr. Opin. Chem. Biol. 2020, 57, 135-154. [CrossRef] [PubMed] 